\title{
COXEN Score 21
}

National Cancer Institute

\section{Source}

National Cancer Institute. COXEN Score 21. NCI Thesaurus. Code C128218.

A score of 21 on the COXEN Sensitivity Scale. 